\title{
SCHEDULING SUPPLEMENTARY DRIP IRRIGATION REQUIREMENTS OF DATE PALM TREES IN SOILS SUBJECTED TO CONTRIBUTION FROM GROUND WATER DEPTHS UNDER EL- FAYOUM CONDITIONS
}

\author{
El-Shakweer, M. H. A. and Ibrahim, A. M. \\ Soils and Water Department, Faculty of Agriculture, Fayoum University, \\ 63514-Fayoum, Egypt.
}

ABSTRACT
Date palm (Phoenix dactylifera, L.) has been focused by researchers to maximize its production (quantity and quality) and more specifically to its water management aiming to find the most effective and economic amounts of water needed for optimum fruit quality.

Three different locations of different soil texture (clay, clay loam and sandy loam) were chosen at Fayoum Governorate. At each location, four sites of different ground water table depth (gwtd), i.e. $\approx 40,80,120$ and $160 \mathrm{~cm}$ already grown with date palm trees; were selected for this study. Within each site 3 date palm trees variety "Balady" aged from 810 years (as replicates) were the task of this study. The selected sites of the tested soils were analyzed for some soil physical and chemical properties. The ground water table depth at each site was measured in an observation well of $10 \mathrm{~cm}$ diameter that was dug to $180 \mathrm{~cm}$ depth, then, the weighted averages of (gwtd) were calculated. The actual evapotranspiration $\left(\mathrm{ET}_{\mathrm{c}}\right)$ of date palm for all the year 2004 under ElFayoum conditions was calculated and the contribution from the tested (gwtd) of the site $\left(\mathrm{ET}_{\text {c.g }}\right)$ to the date palm consumptive use was estimated.

Results showed that the maximum value of total yearly contribution from ground water table to water consumptive use for date palm $(1069.31 \mathrm{~mm})$ was found in the clay soil with the gwtd $(\approx 40 \mathrm{~cm})$, while the minimum value $(161.35 \mathrm{~mm})$ was observed in the sandy loam soil with the gwtd $(\approx 160 \mathrm{~cm})$. Highly significant negative correlations were indicated between the values of total yearly contribution $\left(\mathrm{ET}_{\mathrm{c}-\mathrm{g}}\right.$, $\mathrm{mm}$ ) and the values of (gwtd), and, their simple regression equations showed significant relationships as follows:

For the clay soil $\quad: \mathrm{r}=-0.985$ and $\mathrm{Y}_{1}=1240.50-5.34 \mathrm{X}$.

For the clay loam soil $: r=-0.989$ and $Y_{2}=1215.00-5.75 X$.

For the sandy loam soil : $r=-0.972$ and $Y_{3}=1016.30-5.70 X$.

Where: $\mathrm{Y}$ is the $\mathrm{ET}_{\mathrm{c}-\mathrm{g}}(\mathrm{mm})$ and $\mathrm{X}$ is the gwtd $(\mathrm{cm})$.

Results showed also that the minimum value of the net requirement needs (ETn) for date palm $(414.67 \mathrm{~mm} / \mathrm{year})$ is seen in clayey soil with the gwtd $(\approx 40 \mathrm{~cm})$, while the maximum value $(1322.22 \mathrm{~mm} /$ year) was observed in the sandy loam soil with the gwtd $(\approx 160 \mathrm{~cm})$. Highly significant positive correlations were detected between the values of the net requirements needs (ETn) and that of gwtd, meanwhile, their simple regression equations showed significant relationships as follows:

For the clay soil $\quad: r=+0.965$ and $Y_{1}=249.15+5.31 X$.

For the clay loam soil $: r=+0.971$ and $Y_{2}=266.76+5.79 X$.

For the sandy loam soil $: r=+0.945$ and $Y_{3}=467.10+5.70 X$.

Where: $\mathrm{Y}$ is the ETn (mm/year) and $\mathrm{X}$ is the gwtd $(\mathrm{cm})$.

Fayoum J. Agric. Res. \& Dev., Vol.20, No.1, January, 2006 
SCHEDULING SUPPLEMENTARY DRIP IRRIGATION............ 120

The net requirement needs values (ETn) were considered as the net supplementary drip irrigation requirements (NSDIR) and calculated in $\mathrm{m}^{3} /$ feddan/year for date palm trees. Consequently, scheduling the monthly NSDIR as liter/tree/day through all months of the year, as well as, the needed number of drippers were presented for the application in the studied soils and ground water table depths under Fayoum Governorate conditions.

Key words: Water management, ground water table depth (gwtd), observation well, El-Fayoum conditions, actual evapotranspiration $\left(\mathrm{ET}_{\mathrm{c}}\right)$, contribution from ground water table $\left(\mathrm{ET}_{\mathrm{c} . \mathrm{g}}\right)$, net supplementary drip irrigation requirement (NSDIR).

\section{INTRODUCTION}

Date palm (Phoenix dactylifera, L.) has been cultivated very long time ago. There is archeological evidence of its cultivation in eastern Saudi Arabia in 4000 B.C. It was refered and regarded as a symbol of fertility, and depicted in base relief on coins and paints in some ancient Egyptian tombs.

Date palm production in Egypt covers the whole area of the country from the Mediterranean coast up to Aswan; besides, a big portion of the native production comes from the oasises of Siwa, Bahariya, Farafra, Dakhla and Kharga. Date palm tree is tolerant to high stresses of soil salinity, waterlogging and drought. Meanwhile, its production (quantity and quality) was found sensitive to poor irrigation and drainage conditions (Abu-Khalid et al., 1982). Hussein and Hussein (1983) showed that irrigation treatments of date palm based on twelve water applications per year $\left(300 \mathrm{~m}^{3} /\right.$ feddan each time) at about four weeks intervals is suitable for normal growth of variety Sakkoti date palm in Egypt. Abdelrahman and Al-Nabulsi (1993) concluded that the calculated values in case of using drip irrigation method were $38 \%$ less than that of using surface method for date palm in five regions of date palm in the Kingdom of Saudi Arabia. Hussein et al. (1993) found that irrigation of date palm tree at 40$60 \%$ depletion of total available soil water would be adequate for reasonable date palm production with minimum adverse effect on date fruit quality and quantity. Snyder (1993) reported that crop coefficient values $(\mathrm{Kc})$ are factors that multiplied by ETo to estimate ETc. The $(\mathrm{Kc})$ factors account for crop morphology, crop physiology and water management to some measures of evaporation.

In the eastern and central regions of Saudi Arabia, Al-Omran and Shalaby (1992) found that the total water requirement is $4021 \mathrm{~mm}$ under surface irrigation with water of $\mathrm{EC}=1 \mathrm{dS} / \mathrm{m}$ and there was no reductions in yield due to salinity. Al-Amoud et al. (2000) conducted a field experiment to investigate the response of date palm trees to different water regimes $(50,100$ and $150 \%$ of pan evaporation rate) using three irrigation systems (basin, bubbler and trickle) and they concluded that the maximum yield and water use efficiency were obtained from date palm trees irrigated with trickle irrigation system followed by the basin method. Also, they found a general trend of yield increase as irrigation quantity increased with the tested systems of irrigation. Silmani and Zayani (1998) studied the effect of water regime on the development and yield of young date palm in arid regions, and found that irrigation net-work had an average efficiency of $70 \%$ and the water use efficiency ranged from 0.42 to $0.59 \mathrm{~kg} / \mathrm{m}^{3}$. It was added that, at eight years after planting, a survival rate of 85 $\%$ was recorded with an average monthly water supply of 33-48 mm. Hussain et

Fayoum J. Agric. Res. \& Dev., Vol.20, No.1, January, 2006 
SCHEDULING SUPPLEMENTARY DRIP IRRIGATION........... 121

al. (1993) found that the actual measured daily mean of water requirement of date palm in Al-Hassa, Kingdom of Saudi Arabia is 6.18, 4.84, 2.82 and 1.76 $\mathrm{mm}$ per day. The total annual water requirement of date palm trees were 2256, 1635,1029 , and $642 \mathrm{~mm} \mathrm{ha}^{-1}$ for trees irrigated at $20 \%, 40 \%, 60 \%$, and $80 \%$ moisture depletion of total available soil water. Nail (2003) pointed out that the greatest is obtained water consumptive use of "Seewy" date palm trees variety when irrigation is applied at $60 \%$ of available water $\left(7257 \mathrm{~m}^{3} /\right.$ feddan/year) as compared to irrigation at $20 \%$ of available water $\left(5470 \mathrm{~m}^{3} /\right.$ feddan/year).

The contribution from ground water table is distanced from the bottom of root zone of the cultivated crop and increased with the increase in soil matrix suction of the root zone (Kharshenko et al, 1971 and Ragab and Amer, 1988)). Under El-Fayoum governorate (Egypt) conditions, the previous researches showed a significant contribution from shallow ground water depths to the evapotranspiration and irrigation requirements of cultivated legume crops (ElShakweer et al, 1982 and El-Shakweer, 1985). Aly (2000) found that the contribution values from shallow ground water table depth was $6.51 \%$ in loamy sand soils and was $23.64 \%$ in clay soils to maize crop water requirements. Also, it was found that the contribution values from shallow ground water table depth $21.66 \%$ in loamy sand soils and $22.58 \%$ in clay soils to the wheat crop water requirements. Xainying et al. (1998) found that evapotranspiration values of the three-years old date palm trees are less dependent on the ground water table than those of the two-years old. They concluded that roots of the three years old trees were developed enough to reach soil capillary zone. However, Hussein et al. (1993) reported that fresh weight and fruit volume of date palm did not show significant effect due to different irrigation treatments.

In El-Fayoum governorate (Egypt), date palm trees were grown for long time either in collected farms and/or as disturbed (scattered) trees. According to the Information Center of El-Fayoum Governorate (2004). The total area of collected date palm farms in El-Fayoum Governorate are about 1131.3 feddan (mostly in Senours and Tamia districts), which yield about 9570.8 ton annually (mostly Seewy and Zaghloul varieties). On the other hand, the disturbed (scattered) date palm trees amount to 562306 trees (mostly in Fayoum and Senours districts), which yield about 52120.4 ton annually (mostly Seewy and Amhat varieties) and presently "Zaghloul" cultivar has been introduced to Fayoum as a promising cultivar. Accordingly, the total yield production of date palm varieties in El-Fayoum are about 61691.2 ton/year, which is still below the optimum level of production and urgently needs maximizing.

The aim of this study is to estimate and schedule the net supplementary irrigation requirement needs by drip irrigation system to date palm trees after calculating the expected contribution from the tested ground water table depths in different soils of different textures under El-Fayoum conditions.

\section{MATERIALS AND METHODS}

Three different locations differing in there texture (clay, clay loam and sandy loam) were selected in the year 2004 at Meniet El-hait village Etsa district, Garfas village, Senours district and Menshat Tantawy village, Senours district, Fayoum, Egypt, respectively. At each location, four sites of different ground water table depths i.e. $\approx 40,80,120,160 \mathrm{~cm}$ that already grown with 3 date palm trees, "Balady" variety of ages 8-10 years were chozen for this study. All the tested sites were subjected to the same agricultural management practices. Soil samples from each site were analyzed for physical properties

Fayoum J. Agric. Res. \& Dev., Vol.20, No.1, January, 2006 
SCHEDULING SUPPLEMENTARY DRIP IRRIGATION............ 122 and chemical properties according to Klute (1986) and Page et al. (1982) respectively, as shown in Table (1).

The contribution from ground water table to evapotranspiration and complementary drip irrigation water requirements were estimated according to the following measurements:

Table 1. Physical and chemical properties of the studied soils.

\begin{tabular}{|c|c|c|c|}
\hline \multirow{2}{*}{ Soil property } & \multicolumn{3}{|c|}{ Location } \\
\hline & Meniet El-hait & Garfas & $\begin{array}{l}\text { Menshat } \\
\text { Tantawy }\end{array}$ \\
\hline \multicolumn{4}{|l|}{ Particle size distribution } \\
\hline Coarse sand, $\%$ & 3.46 & 7.34 & 25.40 \\
\hline Fine sand, \% & 15.54 & 31.39 & 53.14 \\
\hline Silt, \% & 32.39 & 27.46 & 6.14 \\
\hline Clay, \% & 48.61 & 33.81 & 15.32 \\
\hline Texture class & Clay & Clay loam & Sandy loam \\
\hline Hydraulic conductivity, $\mathrm{cm} / \mathrm{hr}$ & 0.16 & 0.74 & 2.15 \\
\hline Field capacity, $\%$ & 42.20 & 35.14 & 21.17 \\
\hline Wilting point, \% & 23.30 & 17.87 & 9.06 \\
\hline Available water, $\%$ & 18.90 & 17.27 & 12.11 \\
\hline PH (in soil paste extract) & 7.48 & 7.62 & 7.23 \\
\hline $\mathrm{EC}_{\mathrm{e}}(\mathrm{dS} / \mathrm{m})$ & 3.64 & 3.21 & 1.16 \\
\hline \multicolumn{4}{|l|}{ Soluble cations (meq/l) } \\
\hline $\mathrm{Ca}^{++}$ & 7.38 & 7.14 & 3.71 \\
\hline $\mathrm{Mg}^{++}$ & 5.41 & 4.71 & 2.57 \\
\hline $\mathrm{Na}^{+}$ & 23.33 & 20.57 & 5.86 \\
\hline $\mathrm{K}^{+}$ & 0.63 & 0.59 & 0.18 \\
\hline \multicolumn{4}{|l|}{ Soluble anions (meq/l) } \\
\hline $\mathrm{CO}_{3}=$ & - & - & - \\
\hline $\mathrm{HCO}_{3}^{-}$ & 2.13 & 2.14 & 1.71 \\
\hline $\mathrm{Cl}^{-}$ & 10.50 & 9.71 & 2.57 \\
\hline $\mathrm{SO}_{4}=$ & 24.12 & 21.16 & 8.04 \\
\hline $\mathrm{CaCO}_{3}, \%$ & 4.34 & 6.31 & 7.35 \\
\hline
\end{tabular}

*Each value within the table represents the mean of analysis of layers 0-40, $40-80,80-120$ and $120-160 \mathrm{~cm}$.

1. Measuring ground water table depth (gwtd) and calculating its weighted average (w.av.gwtd):

An observation well of $10 \mathrm{~cm}$ diameter was dug to $180 \mathrm{~cm}$ depth at each of the four sites of all location to measure the depth of the ground water table level by means of a graduated tap, at weekly intervals (Morrison, 1983). Thereafter, their weighted averages were calculated for all the growing season 2004 as shown in Table (2).

Fayoum J. Agric. Res. \& Dev., Vol.20, No.1, January, 2006 
SCHEDULING SUPPLEMENTARY DRIP IRRIGATION.

Table 2. Weighted average of ground water table depth for date palm under the studied soils and depths of ground water.

\begin{tabular}{|l|l|c|c|c|c|}
\hline \multirow{2}{*}{ Location } & Soil texture & \multicolumn{4}{|c|}{ Ground water table depth $(\mathrm{cm})^{*}$} \\
\cline { 3 - 6 } & & $\approx 40$ & $\approx 80$ & $\approx 120$ & $\approx 160$ \\
\hline Meniet El-hait & Clay soil & 39.7 & 79.7 & 120.0 & 160.2 \\
\hline Garfas & Clay loam soil & 40.2 & 80.1 & 119.8 & 160.1 \\
\hline $\begin{array}{l}\text { Menshat } \\
\text { Tantawy }\end{array}$ & $\begin{array}{l}\text { Sandy loam } \\
\text { soil }\end{array}$ & 40.1 & 80.2 & 120.2 & 159.8 \\
\hline
\end{tabular}

*Each value is the mean of 4 replicates.

\section{Calculation of the potential evapotranspiration $\left(\mathbf{E T}_{\mathbf{0}}\right)$ :}

The climatic data presented in Table (3) were used for the calculation of evapotranspiration $\left(\mathrm{ET}_{\mathrm{o}}\right.$ ) using the modified Penman equation as follows (FAO, 1979):

Where:

$$
\mathrm{ET}_{\mathrm{o}}=\mathrm{W} \cdot \mathrm{R}_{\mathrm{n}}+(1-\mathrm{W}) * \mathrm{~F}(\mathrm{U}) *\left(\mathrm{e}_{\mathrm{a}}-\mathrm{e}_{\mathrm{d}}\right) .
$$

$\mathrm{W}$ is the temperature and altitude dependent weighting factor.

$R_{n}$ is the total net radiation as $m m /$ day or $R_{n}=0.75 R_{s}-R_{n} L$.

$R_{S}$ is the incoming short wave radiation in $\mathrm{mm}$ /day either measured or obtained from: $R_{\mathrm{s}}=(0.25+0.5 \mathrm{n} / \mathrm{N}) \mathrm{R}_{\mathrm{a}}$.

$R_{a}$ is extra- terrestrial radiation in $\mathrm{mm} /$ day.

$\mathrm{n}$ is the mean actual sunshine during the day in hour/day.

$\mathrm{N}$ is the maximum possible sunshine duration in hour/day.

$R_{n}$ is the long wave radiation $\mathrm{mm}$ /day as a function of temperature $F(t)$, actual vapour pressure $F\left(e_{d}\right)$ and sunshine duration $F(n / N)$ or calculated

from: $\mathrm{Rn} \mathrm{L}=\mathrm{F}(\mathrm{t}) * \mathrm{~F}(\mathrm{n} / \mathrm{N}) * \mathrm{~F}\left(\mathrm{e}_{\mathrm{d}}\right)$.

$\mathrm{F}(\mathrm{U})$ is the wind function calculated as: $\mathrm{F}(\mathrm{U})=0.27$ (1-U/100), where, (U) measured in $\mathrm{Km} /$ day at $2 \mathrm{~m}$ height.

$\left(e_{a}-e_{d}\right)$ is the vapour pressure defect ,i.e., the difference between the saturation vapour pressure $\left(\mathrm{e}_{\mathrm{a}}\right)$ at mean $\mathrm{T}$ in mbar and the actual vapour pressure $\left(e_{d}\right)$ in mbar. Where, $e_{d}=e_{a} * R H / 100$ and $\mathrm{RH}$ is the relative humidity.

$\mathrm{RnL}$ is the net long wave radiation $\mathrm{mm}$ /day as a function of temperature, $\mathrm{F}(\mathrm{t})$, actual vapour pressure, $\mathrm{F}(\mathrm{ed})$ and sunshine.

\section{Calculation of the water consumptive use $\left(E T_{c}\right)$ of date palm:}

The actual evapotranspiration $\left(\mathrm{ET}_{\mathrm{c}}\right)$ of date palm was calculated according to FAO (1979) as follows: $\quad \mathrm{ET}_{\mathrm{c}}=\mathrm{K}_{\mathrm{c}} * \mathrm{ET}_{\mathrm{o}}$

Where:

$\mathrm{ET}_{\mathrm{o}}$ is the potential evapotranspiration, $\mathrm{mm} /$ day; calculated from Penman equation based on Table (3) data.

$\mathrm{K}_{\mathrm{c}}$ is the crop coefficient for date palm. 
SCHEDULING SUPPLEMENTARY DRIP IRRIGATION

Table 3. Climatic data (2004) used to estimate the reference evapotranspiration (ETo) according to modified Penman under El-Fayoum conditions.

\begin{tabular}{|c|c|c|c|c|c|c|c|c|c|}
\hline \multirow{2}{*}{ Month } & \multicolumn{2}{|c|}{ Temperature, $\mathrm{c}^{\circ}$} & Humidity & $\begin{array}{c}\text { Wind- } \\
\text { speed, } \\
\text { Km/day }\end{array}$ & $\begin{array}{c}\text { Sun- } \\
\text { shine, } \\
\text { Hours }\end{array}$ & $\begin{array}{c}\text { Solar } \\
\text { radiation, } \\
\text { Mj/m } / \text { day }\end{array}$ & $\begin{array}{c}\text { Rain } \\
\text { Fall, } \\
\mathrm{mm}\end{array}$ & $\begin{array}{c}\mathrm{ET}_{\mathrm{o}} \\
\text { Penman } \\
\mathrm{mm} / \text { day }\end{array}$ \\
\hline Jan. & 15.0 & 21.2 & 8.8 & 58.4 & 143 & 6.9 & 12.5 & 2 & 1.8 \\
\hline Feb. & 16.2 & 23.8 & 8.6 & 60.2 & 159 & 7.8 & 15.5 & 0 & 2.1 \\
\hline Mar. & 17.8 & 25.2 & 10.4 & 55.8 & 195 & 8.7 & 19.7 & 0 & 3.9 \\
\hline April & 21.4 & 29.7 & 13.1 & 51.3 & 200 & 9.9 & 23.6 & 0 & 5.1 \\
\hline May & 31.8 & 41.3 & 22.2 & 26.1 & 215 & 10.7 & 25.7 & 0 & 9.9 \\
\hline Jun. & 28.0 & 36.5 & 19.4 & 51.8 & 215 & 11.1 & 26.6 & 0 & 8.1 \\
\hline July & 30.2 & 39.0 & 21.3 & 51.3 & 195 & 13.2 & 29.5 & 0 & 8.5 \\
\hline Aug. & 28.7 & 36.1 & 21.2 & 53.3 & 191 & 12.4 & 27.3 & 0 & 6.3 \\
\hline Sept. & 26.4 & 34.2 & 18.5 & 52.7 & 203 & 11.4 & 23.7 & 0 & 5.8 \\
\hline Oct. & 25.1 & 31.8 & 18.3 & 53.9 & 180 & 9.6 & 18.3 & 0 & 4.2 \\
\hline Nov. & 20.9 & 28.1 & 13.7 & 54.8 & 171 & 7.7 & 13.3 & 0 & 3.2 \\
\hline Dec. & 14.7 & 21.2 & 8.2 & 58.9 & 166 & 6.6 & 10.9 & 8 & 1.8 \\
\hline Year & 23.0 & 30.7 & 15.3 & 52.38 & 185 & 9.6 & 20.7 & 10 & 1855.3 \\
\hline
\end{tabular}

*The used climatic data (2004) was obtained from the Fayoum Agrometoerological Station, where is located at El-Fayoum Governorate (altitude $29.3 \mathrm{~N}^{\circ}$ and longitude $30.85 \mathrm{E}^{\circ}$ ).

\section{Estimation the contribution from ground water table to consumptive use}

(ET c.g $_{\text {. }}$ of date palm:

The contribution from the tested different ground water tables $\left(\mathrm{ET}_{\mathrm{c.g}}\right)$ to date palm evapotranspiration was estimated using the empirical equation presented by Kharshenko et al (1971) as follows:

Where:

$$
\mathrm{ET}_{\mathrm{c} . \mathrm{g}}=\mathrm{ET}_{\mathrm{c}} / \mathrm{K}_{\mathrm{s} . \mathrm{g}}
$$

$\mathrm{ET}_{\mathrm{c}}$ is the actual evapotranspiration for date palm trees.

$\mathrm{ET}_{\mathrm{c.g}}$ is the contribution from the tested ground water table.

$\mathrm{K}_{\mathrm{s}-\mathrm{g}}=\mathrm{e}^{\mathrm{MH}}$. The value of $\mathrm{e}^{\mathrm{MH}}$ is equal to the coefficient for calculating the capillary rise of ground water table $\left(\mathrm{K}_{\mathrm{s.g}}\right)$.

$\mathrm{H}$ is the water table depth in meter.

$\mathrm{M}$ is a parameter depending on soil texture and stage of plant growth.

The calculated $\mathrm{K}_{\mathrm{s}-\mathrm{g}}$ values are presented in the results in Table (5).

\section{RESULTS AND DISCUSSION}

The complementary drip irrigation water requirements for date palm trees were estimated in the three studied soils (clay, clay loam and sandy loam) of different ground water table depths (gwtd) i.e. $\approx 40,80,120$ and $160 \mathrm{~cm}$.

\section{1- Water consumptive use $\left(\mathbf{E T} \mathbf{T}_{\mathrm{c}}\right)$ :}

Table (4) shows the values of water consumptive use $\left(\mathrm{ET}_{\mathrm{c}}\right) \mathrm{mm} / \mathrm{day}$, the potential evapotranspiration $\left(\mathrm{mm} /\right.$ day) and the crop coefficient $\left(\mathrm{K}_{\mathrm{c}}\right)$ during all months of the year 2004. Data in Table (4) show that the water consumptive use values gradually increased from January $(1.39 \mathrm{~mm} /$ day $)$ up to May (8.32 $\mathrm{mm} /$ day $)$, then, the values decreased till December $(1.13 \mathrm{~mm} /$ day $)$. Therefore, the lowest values of $\mathrm{ET}_{\mathrm{c}}$ were obtained during December while the highest were at May. From the obtained results, it could be concluded that the highest increment of $\mathrm{ET}_{\mathrm{c}}$ was in summer months than others, this is attributed to the temperature, wind speed and net radiation, while humidity was lower in

Fayoum J. Agric. Res. \& Dev., Vol.20, No.1, January, 2006 
SCHEDULING SUPPLEMENTARY DRIP IRRIGATION.

summer. These findings and statements are consistent with those mentioned by Ragab and Amer (1988), Caspari et al. (1994), Livett et al. (1995) and Nail (2003).

Table 4. Potential evapotranspiration $\left(\mathrm{ET}_{\mathrm{o}}\right) \mathrm{mm} /$ day, water consumptive use $\left(E_{c}\right) \mathrm{mm} /$ day and crop coefficient $\left(\mathrm{K}_{\mathrm{c}}\right)$ for date palm under Fayoum conditions during the year 2004.

\begin{tabular}{|c|c|c|c|}
\hline Month & $\mathrm{ET}_{\mathrm{o}}$ & $\mathrm{K}_{\mathrm{c}}$ & $\mathrm{ET}_{\mathrm{c}}$ \\
\hline Jan. & 1.8 & 0.77 & 1.39 \\
\hline Feb. & 2.1 & 0.89 & 1.87 \\
\hline Mar. & 3.9 & 0.92 & 3.59 \\
\hline Apr. & 5.1 & 0.90 & 4.59 \\
\hline May & 9.9 & 0.84 & 8.32 \\
\hline Jun. & 8.1 & 0.83 & 6.72 \\
\hline Jul. & 8.5 & 0.79 & 6.72 \\
\hline Aug. & 6.3 & 0.77 & 4.85 \\
\hline Sep. & 5.8 & 0.74 & 4.29 \\
\hline Oct. & 4.2 & 0.70 & 2.94 \\
\hline Nov. & 3.2 & 0.67 & 2.14 \\
\hline Dec. & 1.8 & 0.63 & 1.13 \\
\hline Consumption / year : & 185.53 & - & 148.357 \\
\hline cm & 7792.29 & - & 6230.994 \\
\hline m & \multicolumn{3}{|l}{} \\
\hline
\end{tabular}

2-The coefficient $\left(K_{\mathrm{s}-\mathrm{g}}\right)$ for calculating the capillary rise of ground water under different soil textures and ground water table depths:

Values of the coefficient $\left(\mathrm{K}_{\mathrm{s}-\mathrm{g}}\right)$ for estimating the capillary rise of ground water under different soil textures and ground water table depths are presented in Table (5). The empirical equation presented by Kharshenko et al (1971) was used for estimating the capillary rise $\left(\mathrm{K}_{\mathrm{s}-\mathrm{g}}\right)$ as follows:

$\mathrm{K}_{\mathrm{s}-\mathrm{g}}=\mathrm{ET}_{\mathrm{O}} / \mathrm{e}^{\mathrm{mH}} \quad(\mathrm{mm} / \mathrm{day})$

Where: $\mathrm{H}$ is water table depth in meters, and $\mathrm{m}$ is a parameter that depends on soil texture and stage of plant growth.

Table 5. Coefficient values $\left(\mathrm{K}_{\mathrm{s}-\mathrm{g}}\right)$ for calculating the capillary rise of ground water table under different soils and ground water table depths.

\begin{tabular}{|l|c|c|c|c|}
\hline \multirow{2}{*}{ Soil texture } & \multicolumn{4}{|c|}{ water table depth $(\mathrm{cm})$} \\
\cline { 2 - 5 } & $\approx 40$ & \multicolumn{4}{|c|}{$\approx 80$} & $\mathrm{~K}_{\text {s-g }}$ values \\
\cline { 2 - 5 } & 1.387 & 1.923 & 2.667 & $\approx 120$ \\
\hline Clay & 1.453 & 2.111 & 3.068 & 4.456 \\
\hline Clay loam & 1.740 & 3.027 & 5.267 & 9.163 \\
\hline Sandy loam & \multicolumn{4}{|c|}{} \\
\hline
\end{tabular}

Fayoum J. Agric. Res. \& Dev., Vol.20, No.1, January, 2006 


\section{3- Contribution from ground water table $\left(E T_{\mathrm{c}-\mathrm{g}}\right)$ to evapotranspiration of date palm under different soil textures and ground water table depths:}

Table (6) shows the monthly contribution from ground water table $\left(\mathrm{ET}_{\mathrm{c}-\mathrm{g}}\right)$ to evapotranspiration under the studied soil textures and ground water depths as calculated according to the previously mentioned equation: $\mathrm{ET}_{\text {c.g }}=\mathrm{ETc} / \mathrm{K}_{\mathrm{s.g}}$. Data in table (6), show that the maximum values for contribution of ground water table (ET c-g) to water consumptive use $(6.00 \mathrm{~mm} /$ day) were associated with the heavy textured soils (clay soil) under shallow ground water table depth $(\approx 40 \mathrm{~cm})$ during May 2004, while the minimum values for contribution $(0.12$ $\mathrm{mm} /$ day) were obtained for the light textured soil (sandy loam soil) under deep ground water table $(\approx 160 \mathrm{~cm})$ during December 2004 .

Data in table (6) also indicated that the values of $\left(\mathrm{ET}_{\mathrm{c}-\mathrm{g}}\right)$ were decreased in all of the tested soils with the increase in ground water table depth up to $40 \mathrm{~cm}$. $\left(\mathrm{ET}_{\mathrm{c}-\mathrm{g}}\right)$ values were highest in May for all the tested soils and ground water depths.

Data in table (7) and Figure (1) show the calculated values of total yearly contribution $\left(\mathrm{ET}_{\mathrm{c}-\mathrm{g}}, \mathrm{mm}\right)$ and their percentages from ground water table values relative to total water consumptive use $\left(\mathrm{ET}_{\mathrm{c}}\right)$ calculated according to the following equation:

$$
\text { Contribution \% }=\left(\mathrm{ET}_{\mathrm{c}-\mathrm{g}} / \mathrm{ET}_{\mathrm{c}}\right) * 100
$$

The maximum percentage of total yearly contribution from ground water table to water consumptive use for date palm $(72.07 \%)$ was associated with the clay soil under the $(\approx 40 \mathrm{~cm})$ ground water table depth, while the minimum value $(10.88 \%)$ was observed in the sandy loam soil with the $(\approx 160 \mathrm{~cm})$ ground water table depth. It can be concluded that the contribution percentages from the ground water table depth to date palm tree irrigation requirements are affected by each of the rate and extent of the capillary rise, the moisture and aeration conditions, the ability of crop roots to reach the capillary fringe and by the climatic conditions.

Simple correlation and regression analysis were applied in an attempt to describe the relationship between the total yearly contribution values from ground water table $\left(\mathrm{ET}_{\mathrm{c}-\mathrm{g}}, \mathrm{mm}\right)$ and ground water table depth. Data obtained are shown in Figure (1). It is clear that there is a highly significant negative correlation between the values of total yearly contribution $\left(\mathrm{ET}_{\mathrm{c}-\mathrm{g}}, \mathrm{mm}\right)$ and the ground water table depth in the clay soil $\left(r_{1}=-0.985\right)$, clay loam $\left(r_{2}=-0.989\right)$ and sandy loam soil $\left(r_{3}=-0.972\right)$. The obtained regression equations were as follows:

$\mathrm{Y}_{1}=1240.50-5.34 \mathrm{X}$ (for the studied clay soil)

$\mathrm{Y}_{2}=1215.00-5.75 \mathrm{X}$ (for the studied clay loam soil)

$\mathrm{Y}_{3}=1016.30-5.70 \mathrm{X} \quad$ (for the studied sandy loam soil)

Where:

$\mathrm{Y}$ is the total yearly contribution from ground water table $\left(\mathrm{ET}_{\mathrm{c}-\mathrm{g}}, \mathrm{mm}\right)$.

$\mathrm{X}$ is the ground water table depth $(\mathrm{cm})$.

These equations indicate that there are decreases in the contribution values from ground water table $\left(\mathrm{ET}_{\mathrm{c}-\mathrm{g}}, \mathrm{mm}\right)$ equal to $5.34,5.75$ and 5.70 for every one $\mathrm{cm}$ of ground water table depth for each of clay $\left(\mathrm{Y}_{1}\right)$, clay loam $\left(\mathrm{Y}_{2}\right)$ and sandy loam soils $\left(\mathrm{Y}_{3}\right)$, respectively. The above-mentioned findings and statements may cope with those stated by Hassan (1980), Ibrahim (1983), Jensen et al. (1990) and Paratap et al. (1994). In this connection, Al-Kafaf et al.

Fayoum J. Agric. Res. \& Dev., Vol.20, No.1, January, 2006 
SCHEDULING SUPPLEMENTARY DRIP IRRIGATION............ 127 (1998) reported that the effective crop rooting zone volume refers to the volume of the soil at which roots extract $80 \%$ of the water utilized by the tree. They also found significant increases was indicated in both the vertical and horizontal root distribution from planting the offshoots to the seventh year, but no significant increase in root distribution was detected after the seventh year.

Table 6. Contribution from ground water table (ET c-g, $\mathrm{mm} /$ day) to water consumptive use of date palm and their percentages during the year 2004 as affected by soil texture and ground water table depth.

\begin{tabular}{|c|c|c|c|c|c|c|c|c|c|c|c|c|c|c|}
\hline \multirow{2}{*}{ 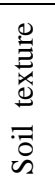 } & \multirow{2}{*}{$\begin{array}{c}\text { Ground } \\
\text { water } \\
\text { table } \\
(\mathrm{cm})\end{array}$} & \multirow{2}{*}{$\begin{array}{c}\mathrm{ET}_{\mathrm{c.g}} \\
\text { as }\end{array}$} & \multicolumn{12}{|c|}{ Month } \\
\hline & & & Jan. & Feb. & Mar. & Apr. & May & Jun. & Jul. & Aug. & Sep. & Oct. & Nov. & Dec. \\
\hline \multirow{8}{*}{$\frac{\vec{\Xi}}{U}$} & \multirow[b]{2}{*}{40} & $\mathrm{~mm} / \mathrm{d}$ & 1.00 & 1.35 & 2.59 & 3.31 & 6.00 & 4.84 & 4.84 & 3.50 & 3.09 & 2.12 & 1.54 & 0.81 \\
\hline & & $\% *$ & 71.9 & 72.2 & 72.1 & 72.1 & 72.1 & 72.0 & 72.0 & 72.2 & 72.0 & 72.1 & 72.0 & 71.7 \\
\hline & \multirow[b]{2}{*}{80} & $\mathrm{~mm} / \mathrm{d}$ & 0.72 & 0.97 & 1.87 & 2.39 & 4.32 & 3.50 & 3.50 & 2.52 & 2.23 & 1.53 & 1.11 & 0.59 \\
\hline & & $\% *$ & 51.8 & 51.9 & 52.1 & 52.1 & 51.9 & 52.1 & 52.1 & 52.0 & 51.9 & 52.0 & 51.9 & 52.2 \\
\hline & \multirow[b]{2}{*}{120} & $\mathrm{~mm} / \mathrm{d}$ & 0.52 & 0.72 & 1.35 & 1.72 & 3.12 & 2.52 & 2.52 & 1.82 & 1.61 & 1.10 & 0.80 & 0.42 \\
\hline & & $\% *$ & 37.4 & 38.5 & 37.6 & 37.5 & 37.5 & 37.5 & 37.5 & 37.5 & 37.5 & 37.4 & 37.4 & 37.2 \\
\hline & \multirow[b]{2}{*}{160} & $\mathrm{~mm} / \mathrm{d}$ & 0.41 & 0.55 & 0.97 & 1.35 & 2.45 & 1.98 & 1.98 & 1.43 & 1.16 & 0.80 & 0.63 & 0.33 \\
\hline & & $\% *$ & 29.5 & 29.4 & 27.0 & 29.4 & 29.5 & 29.5 & 29.3 & 29.5 & 27.0 & 27.2 & 29.4 & 29.2 \\
\hline \multirow{8}{*}{ 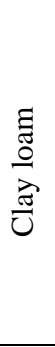 } & \multirow[b]{2}{*}{40} & $\mathrm{~mm} / \mathrm{d}$ & 0.96 & 1.29 & 2.47 & 3.16 & 5.73 & 4.62 & 4.62 & 3.34 & 2.95 & 2.02 & 1.47 & 0.78 \\
\hline & & $\% *$ & 69.1 & 69.0 & 68.8 & 68.8 & 68.9 & 68.8 & 68.8 & 68.9 & 68.7 & 68.7 & 68.7 & 69.0 \\
\hline & \multirow[b]{2}{*}{80} & $\mathrm{~mm} / \mathrm{d}$ & 0.66 & 0.89 & 1.70 & 2.17 & 3.94 & 3.18 & 3.18 & 2.30 & 2.03 & 1.39 & 1.01 & 0.54 \\
\hline & & $\% *$ & 47.5 & 47.6 & 47.3 & 47.3 & 47.4 & 47.3 & 47.3 & 47.4 & 47.3 & 47.3 & 47.2 & 47.8 \\
\hline & \multirow[b]{2}{*}{120} & $\mathrm{~mm} / \mathrm{d}$ & 0.45 & 0.61 & 1.17 & 1.50 & 2.71 & 2.19 & 2.19 & 1.58 & 1.40 & 0.96 & 0.70 & 0.37 \\
\hline & & $\% *$ & 32.4 & 32.6 & 32.6 & 32.7 & 32.6 & 32.6 & 32.6 & 32.6 & 32.6 & 32.6 & 32.7 & 32.7 \\
\hline & \multirow[b]{2}{*}{160} & $\mathrm{~mm} / \mathrm{d}$ & 0.31 & 0.42 & 0.81 & 1.03 & 1.87 & 1.51 & 1.51 & 1.09 & 0.96 & 0.66 & 0.48 & 0.25 \\
\hline & & $\% *$ & 22.3 & 22.5 & 22.6 & 22.4 & 22.5 & 22.5 & 22.6 & 22.5 & 22.4 & 22.4 & 22.4 & 22.1 \\
\hline \multirow{8}{*}{ 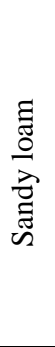 } & \multirow[b]{2}{*}{40} & $\mathrm{~mm} / \mathrm{d}$ & 0.80 & 1.08 & 2.06 & 2.64 & 4.78 & 3.86 & 3.86 & 2.79 & 2.47 & 1.69 & 1.23 & 0.65 \\
\hline & & $\% *$ & 57.6 & 57.8 & 57.4 & 57.5 & 57.5 & 57.4 & 57.4 & 57.5 & 57.6 & 57.5 & 57.5 & 57.5 \\
\hline & \multirow[b]{2}{*}{80} & $\mathrm{~mm} / \mathrm{d}$ & 0.40 & 0.62 & 1.18 & 1.52 & 2.75 & 2.22 & 2.22 & 1.60 & 1.42 & 0.97 & 0.71 & 0.37 \\
\hline & & $\% *$ & 34.5 & 33.2 & 32.9 & 33.1 & 33.1 & 33.0 & 33.0 & 33.0 & 33.9 & 32.9 & 33.2 & 32.7 \\
\hline & \multirow[b]{2}{*}{120} & $\mathrm{~mm} / \mathrm{d}$ & 0.26 & 0.36 & 0.68 & 0.87 & 1.58 & 1.28 & 1.28 & 0.92 & 0.81 & 0.56 & 0.41 & 0.22 \\
\hline & & $\% *$ & 18.7 & 19.3 & 18.9 & 19.0 & 19.0 & 19.0 & 19.0 & 19.0 & 18.9 & 19.0 & 19.2 & 19.5 \\
\hline & \multirow[b]{2}{*}{160} & $\mathrm{~mm} / \mathrm{d}$ & 0.15 & 0.20 & 0.39 & 0.50 & 0.91 & 0.73 & 0.73 & 0.53 & 0.47 & 0.32 & 0.23 & 0.12 \\
\hline & & $\% *$ & 10.8 & 10.7 & 10.9 & 10.9 & 10.9 & 10.9 & 10.9 & 10.9 & 10.9 & 10.9 & 10.8 & 10.6 \\
\hline
\end{tabular}

*As \% of the calculated water consumptive use (ETc).

Table 7. Total yearly contribution from ground water table to water consumptive use of date palm $\left(\mathrm{ET}_{\mathrm{c}-\mathrm{g}}, \mathrm{mm}\right)$ and it their percentages as affected by soil texture and ground water table depth.

\begin{tabular}{|l|c|c|c|c|c|c|c|c|}
\hline \multirow{3}{*}{$\begin{array}{c}\text { Soil } \\
\text { texture }\end{array}$} & \multicolumn{9}{|c|}{ Ground water table depth $(\mathrm{cm})$} \\
\cline { 2 - 9 } & $\mathrm{ET}_{\mathrm{c}-\mathrm{g}}$ & $\% *$ & $\mathrm{ET}_{\mathrm{c}-\mathrm{g}}$ & $\% *$ & \multicolumn{2}{c|}{$\approx 120$} & \multicolumn{2}{c|}{$\approx 160$} \\
\hline & 1069.21 & 72.07 & 771.58 & 52.01 & 556.73 & 37.53 & 429.02 & 28.92 \\
\hline Clay & 1020.93 & 68.82 & 721.12 & 48.61 & 483.72 & 32.61 & 333.08 & 22.45 \\
\hline Clay loam & 852.85 & 57.49 & 488.27 & 32.91 & 282.04 & 19.01 & 161.35 & 10.88 \\
\hline Sandy loam & 85 &
\end{tabular}

- As \% of the calculated water consumptive use (ETc).

Fayoum J. Agric. Res. \& Dev., Vol.20, No.1, January, 2006 


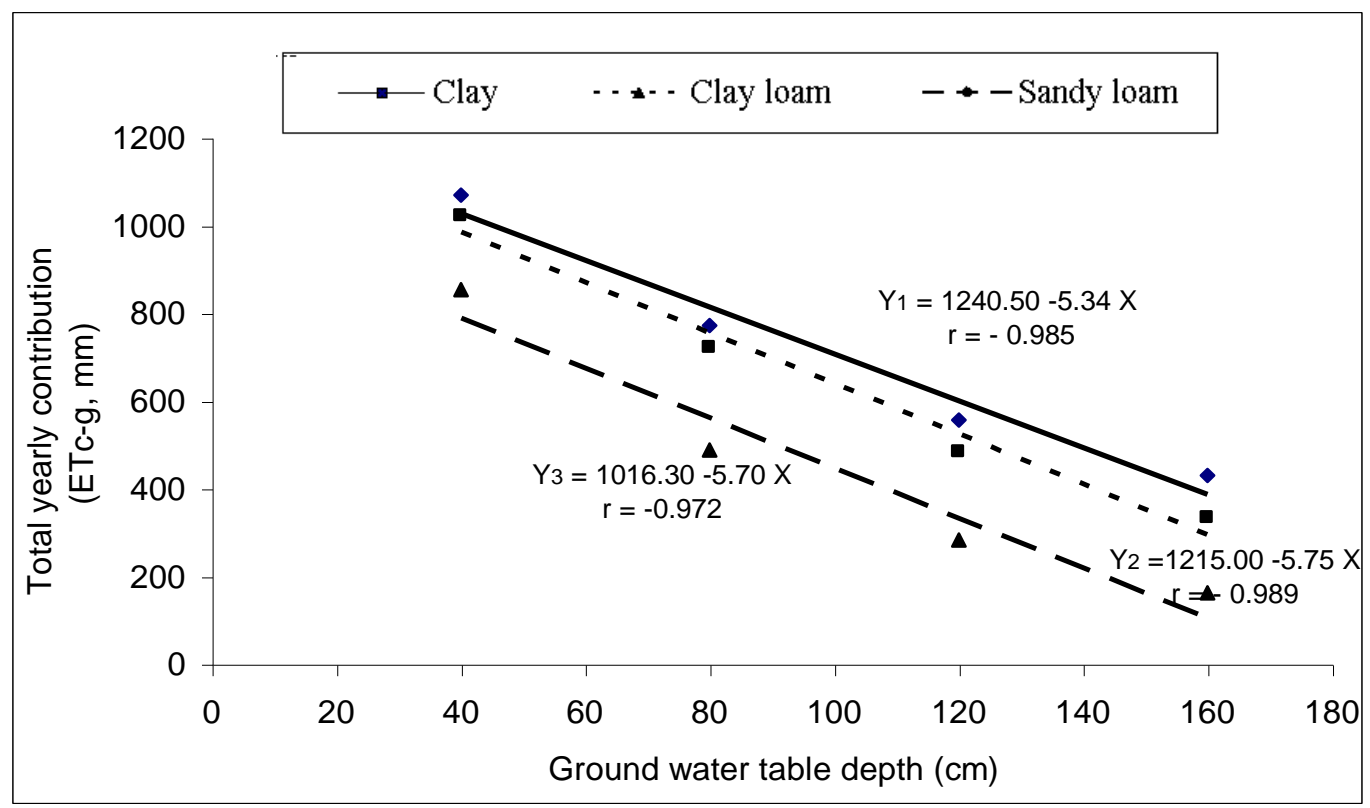

Figure 1. Total yearly contribution from ground water table to water consumptive use of date palm (ET $\left.\mathrm{c}_{\mathrm{c}-\mathrm{g}}, \mathrm{mm} / \mathrm{year}\right)$ as affected by soil texture and ground water table depth.

Where: $Y_{1}, Y_{2}$ and $Y_{3}$ is the total yearly contribution from ground water table depth $\left(\mathrm{ET}_{\mathrm{c}-\mathrm{g}}\right.$, $\mathrm{mm} / \mathrm{year}$ ) in the clay, clay loam and sandy loam soils, respectively and $\mathrm{X}$ is the ground water table depth $(\mathrm{cm})$.

\section{4- Net evapotranspiration $\left(E T_{n}\right)$ by date palm under different soil textures and} ground water table depths:

Table (8) shows the net evapotranspiration $\left(\mathrm{ET}_{\mathrm{n}}\right)$ values of date palm under different soil textures and ground water depths that calculated by difference as follows: $\mathrm{ET}_{\mathrm{n}}=\mathrm{ET}_{\mathrm{c}}-\mathrm{ET} \mathrm{c}-\mathrm{g}$.

The minimum net evapotranspiration $\left(\mathrm{ET}_{\mathrm{n}}\right)$ values $(0.32 \mathrm{~mm} /$ day $)$ for date palm trees were obtained at the tested heavy textured soil (clay soil) with shallow ground water table $(\approx 40 \mathrm{~cm})$ during December 2004 , while the maximum values (7.41 $\mathrm{mm}$ /day) were observed with the light textured soil (sandy soil) under $(\approx 160 \mathrm{~cm})$ ground water table depth during May 2004. Maximum values of the net evapotranspiration $\left(\mathrm{ET}_{\mathrm{n}}\right)$ were detected during May for all the studied soils.

Data in table (9) and Figure (2) indicated that the net evapotranspiration values were decreased in all the studied soils when ground water table depth decreased from 160 to 120,80 and $40 \mathrm{~cm}$., respectively. Mostly, the values of $\left(\mathrm{ET}_{\mathrm{n}}\right)$ were increased in light textured soils morethan the clay soil. Simple correlation and regression analysis were applied in an attempt to describe the relationship between the net evapotranspiration (ETn, mm/year) values and ground water table depth. Results of analysis are shown in Figure (2). It is clear that there is a highly significant positive correlation between the net evapotranspiration (ETn, mm/year) values in the clay soil $\left(r_{1}=0.965\right)$, clay loam $\left(r_{2}=0.971\right)$ and sandy loam soil $\left(r_{3}=0.945\right)$. The obtained regression equations were as follows:

$\mathrm{Y}_{1}=249.15+5.31 \mathrm{X}$ (for the studied clay soil)

$\mathrm{Y}_{2}=266.76+5.79 \mathrm{X}$ (for the studied clay loam soil)

$\mathrm{Y}_{3}=467.10+5.70 \mathrm{X}$ (for the studied sandy loam soil)

Fayoum J. Agric. Res. \& Dev., Vol.20, No.1, January, 2006 
SCHEDULING SUPPLEMENTARY DRIP IRRIGATION............

Where:

$\mathrm{Y}$ is the net requirements needs (ETn, mm/year).

$\mathrm{X}$ is the ground water table depth $(\mathrm{cm})$.

Calculated increases in the net evapotranspiration (ETn, $\mathrm{mm} / \mathrm{year}$ ) values were 5.31, 5.79 and 5.70 for every one $\mathrm{cm}$ of ground water table depth for each of clay $\left(\mathrm{Y}_{1}\right)$, clay loam $\left(\mathrm{Y}_{2}\right)$ and sandy loam soils $\left(\mathrm{Y}_{3}\right)$, respectively. These results may be due to the increase in the capillary rise of clay soil than the sandy loam soil, and to the associated increases in meteorological factors especially temperature at summer season.

Table 8. Net evapotranspiration $\left(\mathrm{ET}_{\mathrm{n}}, \mathrm{mm} / \mathrm{day}\right)$ values of date palm during the year 2004 as affected by soil texture and ground water table depth.

\begin{tabular}{|c|c|c|c|c|c|c|c|c|c|c|c|c|c|c|}
\hline \multirow{2}{*}{ 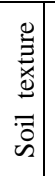 } & \multirow{2}{*}{$\begin{array}{c}\text { Ground } \\
\text { water } \\
\text { table } \\
(\mathrm{cm}) \\
\end{array}$} & \multirow{2}{*}{$\begin{array}{c}\mathrm{ET}_{\mathrm{n}} \\
\text { as }\end{array}$} & \multicolumn{12}{|c|}{ Month } \\
\hline & & & Jan. & Feb. & Mar. & Apr. & May & Jun. & Jul. & Aug. & Sep. & Oct. & Nov. & Dec. \\
\hline \multirow{8}{*}{$\frac{\vec{\Xi}}{U}$} & \multirow[b]{2}{*}{40} & $\mathrm{~mm} / \mathrm{d}$ & 0.39 & 0.52 & 1.00 & 1.28 & 2.32 & 1.88 & 1.88 & 1.36 & 1.20 & 0.82 & 0.60 & 0.32 \\
\hline & & $\% *$ & 28.1 & 27.8 & 27.8 & 27.9 & 27.9 & 28.0 & 28.0 & 27.8 & 27.9 & 27.9 & 28.0 & 28.3 \\
\hline & \multirow[b]{2}{*}{80} & $\mathrm{~mm} / \mathrm{d}$ & 0.67 & 0.90 & 1.72 & 2.20 & 4.00 & 3.22 & 3.22 & 2.33 & 2.06 & 1.41 & 1.03 & 0.54 \\
\hline & & $\% *$ & 48.2 & 48.1 & 47.9 & 47.9 & 48.1 & 47.9 & 47.9 & 48.0 & 48.0 & 47.9 & 48.1 & 47.8 \\
\hline & \multirow[t]{2}{*}{120} & $\mathrm{~mm} / \mathrm{d}$ & 0.87 & 1.15 & 1.72 & 2.87 & 5.20 & 4.20 & 4.20 & 3.03 & 2.06 & 1.41 & 1.34 & 0.71 \\
\hline & & $\% *$ & 62.6 & 61.5 & 47.9 & 62.5 & 62.5 & 62.5 & 62.5 & 62.5 & 48.0 & 47.9 & 62.6 & 62.8 \\
\hline & \multirow[b]{2}{*}{160} & $\mathrm{~mm} / \mathrm{d}$ & 0.98 & 1.32 & 2.62 & 3.27 & 5.87 & 4.74 & 4.74 & 3.42 & 3.13 & 2.14 & 1.51 & 0.80 \\
\hline & & $\% *$ & 70.5 & 70.6 & 72.9 & 71.2 & 70.6 & 70.5 & 70.5 & 70.5 & 72.9 & 72.8 & 70.6 & 70.8 \\
\hline \multirow{8}{*}{ 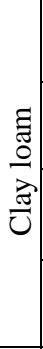 } & \multirow[b]{2}{*}{40} & $\mathrm{~mm} / \mathrm{d}$ & 0.43 & 0.58 & 1.12 & 1.43 & 2.59 & 2.10 & 2.10 & 1.51 & 1.34 & 0.92 & 0.67 & 0.35 \\
\hline & & $\% *$ & 30.9 & 31.0 & 31.2 & 31.3 & 31.1 & 31.3 & 31.3 & 31.1 & 31.2 & 31.3 & 31.3 & 31.0 \\
\hline & \multirow[b]{2}{*}{80} & $\mathrm{~mm} / \mathrm{d}$ & 0.73 & 0.98 & 1.89 & 2.42 & 4.38 & 3.54 & 3.54 & 2.55 & 2.26 & 1.55 & 1.13 & 0.59 \\
\hline & & $\% *$ & 52.5 & 52.7 & 52.6 & 52.7 & 52.6 & 52.7 & 52.7 & 52.6 & 52.7 & 52.7 & 52.8 & 52.2 \\
\hline & \multirow[b]{2}{*}{120} & $\mathrm{~mm} / \mathrm{d}$ & 0.94 & 1.26 & 2.42 & 3.09 & 5.61 & 4.53 & 4.53 & 3.27 & 2.89 & 1.98 & 1.44 & 0.76 \\
\hline & & $\% *$ & 67.6 & 67.4 & 67.4 & 67.3 & 67.4 & 67.4 & 67.4 & 67.4 & 67.3 & 67.3 & 67.3 & 67.3 \\
\hline & \multirow[b]{2}{*}{160} & $\mathrm{~mm} / \mathrm{d}$ & 1.08 & 1.45 & 2.78 & 3.56 & 6.45 & 5.21 & 5.21 & 3.76 & 3.33 & 2.28 & 1.66 & 0.88 \\
\hline & & $\% *$ & 77.7 & 77.5 & 77.4 & 77.6 & 77.5 & 77.5 & 77.5 & 77.5 & 77.6 & 77.5 & 77.6 & 77.9 \\
\hline \multirow{8}{*}{ 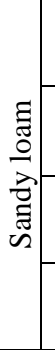 } & \multirow[b]{2}{*}{40} & $\mathrm{~mm} / \mathrm{d}$ & 0.59 & 0.79 & 1.53 & 1.95 & 3.54 & 2.86 & 2.86 & 2.06 & 1.82 & 1.25 & 0.91 & 0.48 \\
\hline & & $\% *$ & 42.4 & 42.2 & 42.6 & 42.5 & 42.5 & 42.6 & 42.6 & 42.5 & 42.4 & 42.5 & 42.5 & 42.5 \\
\hline & \multirow[b]{2}{*}{80} & $\mathrm{~mm} / \mathrm{d}$ & 0.99 & 1.25 & 2.40 & 3.07 & 5.57 & 4.50 & 4.50 & 3.25 & 2.87 & 1.97 & 1.43 & 0.76 \\
\hline & & $\% *$ & 71.2 & 66.8 & 66.8 & 66.9 & 66.9 & 67.0 & 67.0 & 67.0 & 66.9 & 67.0 & 66.8 & 67.3 \\
\hline & \multirow[b]{2}{*}{120} & $\mathrm{~mm} / \mathrm{d}$ & 1.13 & 1.51 & 2.91 & 3.72 & 6.74 & 5.44 & 5.44 & 3.93 & 3.48 & 2.38 & 1.73 & 0.91 \\
\hline & & $\% *$ & 81.3 & 80.7 & 81.1 & 81.1 & 81.0 & 81.0 & 81.0 & 81.0 & 81.1 & 80.9 & 80.8 & 80.5 \\
\hline & \multirow[b]{2}{*}{160} & $\mathrm{~mm} / \mathrm{d}$ & 1.24 & 1.67 & 3.20 & 4.09 & 7.41 & 5.99 & 5.99 & 4.32 & 3.82 & 2.62 & 1.91 & 1.01 \\
\hline & & $\% *$ & 89.2 & 89.3 & 89.1 & 89.1 & 89.1 & 89.1 & 89.1 & 89.1 & 89.0 & 89.1 & 89.3 & 89.4 \\
\hline
\end{tabular}

$*$ As $\%$ of the calculated water consumptive use (ETc).

Table 9. Total yearly net evapotranspiration $\left(\mathrm{ET}_{\mathrm{n}}, \mathrm{mm}\right)$ values by date palm and their percentages as affected by soil texture and ground water table depth.

\begin{tabular}{|c|c|c|c|c|c|c|c|c|}
\hline \multirow{3}{*}{$\begin{array}{c}\text { Soil } \\
\text { texture }\end{array}$} & \multicolumn{8}{|c|}{ Ground water table depth $(\mathrm{cm})$} \\
\hline & \multicolumn{2}{|c|}{$\approx 40$} & \multicolumn{2}{|c|}{$\approx 80$} & \multicolumn{2}{|c|}{$\approx 120$} & \multicolumn{2}{|c|}{$\approx 160$} \\
\hline & $\mathrm{ET}_{\mathrm{n}}$ & $\% *$ & $\mathrm{ET}_{\mathrm{n}}$ & $\% *$ & $\mathrm{ET}_{\mathrm{n}}$ & $\% *$ & $\mathrm{ET}_{\mathrm{n}}$ & $\% *$ \\
\hline Clay & 414.67 & 27.95 & 724.41 & 48.83 & 926.84 & 62.47 & 1055.45 & 71.14 \\
\hline Clay loam & 451.48 & 30.43 & 781.05 & 52.65 & 999.85 & 67.39 & 1150.49 & 77.55 \\
\hline Sandy loam & 630.72 & 42.51 & 994.99 & 67.07 & 1201.53 & 80.99 & 1322.22 & 89.12 \\
\hline
\end{tabular}

*As \% of the calculated water consumptive use (ETc).

Fayoum J. Agric. Res. \& Dev., Vol.20, No.1, January, 2006 

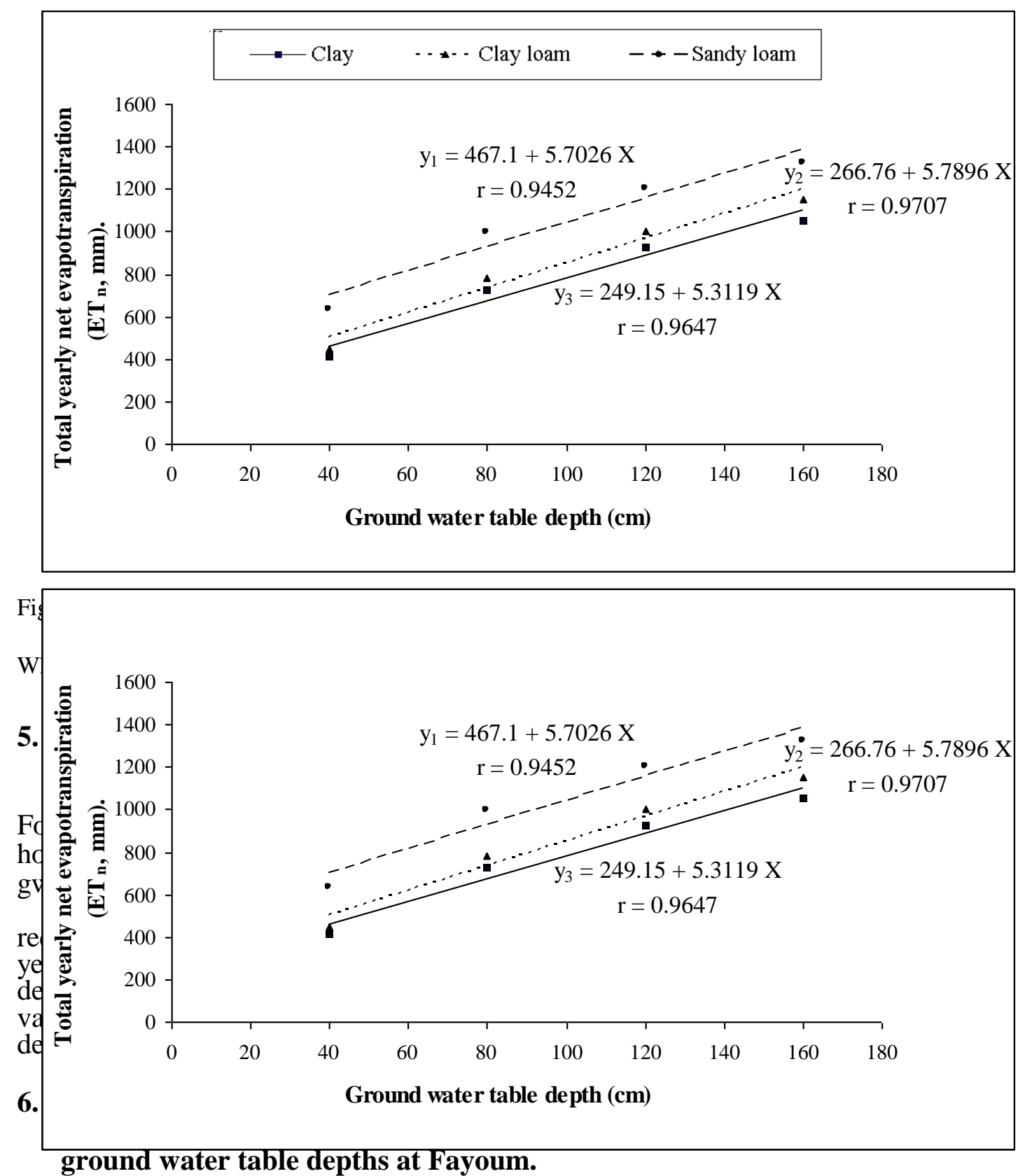

Data in table (11) show that the maximum complementary net irrigation requirements values as $\mathrm{m}^{3} / \mathrm{fed}$./day were needed during May while the minimum needs were at December, 2004.

The complementary net irrigation requirements as (liter/ date palm tree/day) under the tested soil textures and ground water table depths, are given in table (11) and were calculated as follows (one feddan $=4200$ square meters):

Net irrigation requirements $(\mathrm{L} /$ tree/month $)=($ Maximum net irrigation requirements during May month $/ 42) * 1000$

This was applied on the bases that: One feddan contains 42 date palm trees when the spacing between trees is $10 \mathrm{~m} \times 10 \mathrm{~m}$ (as recommended).

Fayoum J. Agric. Res. \& Dev., Vol.20, No.1, January, 2006 
Considering that a dripper discharge is 40 liter/day, the calculated number of drippers needed /tree is shown in Table (11). Data obtained indicated that the drippers number needed/tree in the drip irrigation system is depended on ground water table depth and soil texture class, where, the needed number of drippers increased in the sandy loam compared with the clay soil especially in May under deeper ground water table. Salvadore and Smajstrla (1996) reported that applying water by drip irrigation is related to the amount of water evaporated. They added that the water service class A pan would be a convenient method to schedule irrigation as these pan evaporation data are generally available in most farming areas.

Table 10. Implementing the complementary net irrigation requirements $\mathrm{ET}_{\mathrm{n}}$, $\left(\mathrm{m}^{3} /\right.$ fed./day) during the growth season of date palm grown under different soil textures and ground water table depths and the total yearly net irrigation requirements $\left(\mathrm{m}^{3} /\right.$ fed./year)

\begin{tabular}{|c|c|c|c|c|c|c|c|c|c|c|c|c|c|c|}
\hline \multirow{2}{*}{ 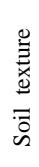 } & \multirow{2}{*}{$\begin{array}{l}\text { Ground } \\
\text { water } \\
\text { table } \\
(\mathrm{cm})\end{array}$} & \multicolumn{12}{|c|}{ Month } & \multirow{2}{*}{$\begin{array}{c}\text { Total } \\
\text { net irri. } \\
\text { require. } \\
\left(\mathrm{m}^{3} / \text { fed. }\right. \\
\text { / year) }\end{array}$} \\
\hline & & Jan & Feb. & Mar. & Apr. & May & Jun. & Jul. & Aug. & Sep. & Oct. & Nov. & Dec & \\
\hline \multirow{4}{*}{$\frac{\vec{\Xi}}{U}$} & 40 & 1.64 & 2.18 & 4.20 & 5.38 & 9.74 & 7.90 & 7.90 & 5.71 & 5.04 & 3.44 & 2.52 & 1.34 & 1741.614 \\
\hline & 80 & 2.81 & 3.78 & 7.22 & 9.24 & 16.80 & 13.52 & 13.52 & 9.79 & 8.65 & 5.92 & 4.33 & 2.27 & 2990.358 \\
\hline & 120 & 3.65 & 4.83 & 9.41 & 12.05 & 21.84 & 17.64 & 17.64 & 12.73 & 11.26 & 7.73 & 5.63 & 2.98 & 3892.608 \\
\hline & 160 & 4.12 & 5.54 & 11.00 & 13.61 & 24.65 & 19.91 & 19.91 & 14.36 & 13.15 & 8.98 & 6.34 & 3.36 & 4429.170 \\
\hline \multirow{4}{*}{$\underset{\dot{d}}{\dot{d}}$} & 40 & 1.81 & 2.44 & 4.70 & 6.01 & 10.88 & 8.82 & 8.82 & 6.34 & 5.63 & 3.86 & 2.81 & 1.47 & 1943.088 \\
\hline & 80 & 3.07 & 4.12 & 7.94 & 10.16 & 18.40 & 14.87 & 14.87 & 10.71 & 9.49 & 6.51 & 4.75 & 2.48 & 3280.410 \\
\hline & 120 & 3.95 & 5.29 & 10.16 & 12.77 & 23.56 & 19.03 & 19.03 & 13.73 & 12.14 & 8.32 & 6.05 & 3.19 & 4193.070 \\
\hline & 160 & 4.54 & 6.09 & 11.68 & 14.95 & 27.09 & 21.88 & 21.88 & 15.79 & 13.99 & 9.58 & 6.97 & 3.70 & 4832.058 \\
\hline \multirow{4}{*}{ 方 } & 40 & 2.48 & 3.32 & 6.43 & 8.19 & 14.87 & 12.01 & 12.01 & 8.65 & 7.64 & 5.25 & 3.82 & 2.02 & 2653.488 \\
\hline & 80 & 4.16 & 5.25 & 10.08 & 12.89 & 23.39 & 18.90 & 18.90 & 13.65 & 12.05 & 8.27 & 6.01 & 3.19 & 4178.958 \\
\hline & 120 & 4.75 & 6.34 & 12.22 & 15.62 & 28.31 & 22.85 & 22.85 & 16.51 & 14.62 & 10.00 & 7.07 & 3.82 & 5046.426 \\
\hline & 160 & 5.21 & 7.01 & 13.44 & 17.18 & 31.12 & 25.16 & 25.16 & 18.14 & 16.04 & 11.00 & 8.02 & 4.24 & 5553.324 \\
\hline
\end{tabular}

Fayoum J. Agric. Res. \& Dev., Vol.20, No.1, January, 2006 
Table 11. Daily complementary required net drip irrigation (L/tree/day) and number of drippers needed per one tree grown under the tested soil textures and ground water table depth at Fayoum.

\begin{tabular}{|c|c|c|c|c|c|c|c|c|c|c|c|c|c|c|}
\hline \multirow{2}{*}{ 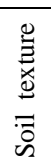 } & \multirow{2}{*}{$\begin{array}{c}\text { Ground } \\
\text { water } \\
\text { table } \\
(\mathrm{cm})\end{array}$} & \multirow{2}{*}{$\begin{array}{c}\text { Net* }^{*} \\
\& \\
\text { ND+ }\end{array}$} & \multicolumn{12}{|c|}{ Month } \\
\hline & & & Jan. & Feb. & Mar. & Apr. & May & Jun. & Jul. & Aug. & Sep. & Oct. & Nov. & Dec. \\
\hline \multirow{8}{*}{$\frac{\overrightarrow{\mathrm{U}}}{\mathrm{U}}$} & \multirow[b]{2}{*}{40} & Net & 39 & 52 & 100 & 128 & 232 & 188 & 188 & 136 & 120 & 82 & 60 & 32 \\
\hline & & ND+ & 1 & 1 & 3 & 3 & 6 & 5 & 5 & 3 & 3 & 2 & 2 & 1 \\
\hline & \multirow[b]{2}{*}{80} & Net & 67 & 90 & 172 & 220 & 400 & 322 & 322 & 233 & 206 & 141 & 103 & 54 \\
\hline & & ND+ & 2 & 2 & 4 & 6 & 10 & 8 & 8 & 6 & 5 & 4 & 3 & 1 \\
\hline & \multirow[b]{2}{*}{120} & Net & 87 & 115 & 224 & 287 & 520 & 420 & 420 & 303 & 268 & 184 & 134 & 71 \\
\hline & & $\mathrm{ND}+$ & 2 & 3 & 6 & 7 & 13 & 10 & 10 & 8 & 7 & 5 & 3 & 2 \\
\hline & \multirow[b]{2}{*}{160} & Net & 98 & 132 & 262 & 324 & 587 & 474 & 474 & 342 & 313 & 214 & 151 & 80 \\
\hline & & ND+ & 2 & 3 & 7 & 8 & 15 & 12 & 12 & 9 & 8 & 5 & 4 & 2 \\
\hline \multirow{8}{*}{ 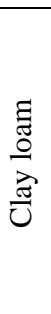 } & \multirow[b]{2}{*}{40} & Net & 43 & 58 & 112 & 143 & 256 & 210 & 210 & 151 & 134 & 92 & 67 & 35 \\
\hline & & ND+ & 1 & 1 & 2 & 4 & 6 & 5 & 5 & 4 & 3 & 2 & 2 & 1 \\
\hline & \multirow[b]{2}{*}{80} & $\mathrm{Net}$ & 73 & 98 & 189 & 242 & 438 & 354 & 354 & 255 & 226 & 155 & 113 & 59 \\
\hline & & $\mathrm{ND}+$ & 2 & 2 & 5 & 6 & 11 & 9 & 9 & 6 & 6 & 4 & 3 & 1 \\
\hline & \multirow[b]{2}{*}{120} & Net & 94 & 126 & 242 & 304 & 561 & 453 & 453 & 327 & 289 & 198 & 144 & 76 \\
\hline & & ND+ & 2 & 3 & 6 & 8 & 14 & 11 & 11 & 8 & 7 & 5 & 4 & 2 \\
\hline & \multirow[b]{2}{*}{160} & Net & 108 & 145 & 278 & 356 & 645 & 521 & 521 & 376 & 333 & 228 & 166 & 88 \\
\hline & & ND+ & 3 & 4 & 7 & 9 & 16 & 13 & 13 & 9 & 8 & 6 & 4 & 2 \\
\hline \multirow{8}{*}{ 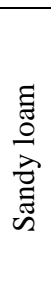 } & \multirow[b]{2}{*}{40} & Net & 59 & 79 & 153 & 195 & 354 & 286 & 286 & 206 & 182 & 125 & 91 & 48 \\
\hline & & $\mathrm{ND}+$ & 1 & 2 & 4 & 5 & 9 & 7 & 7 & 5 & 5 & 3 & 2 & 1 \\
\hline & \multirow[b]{2}{*}{80} & Net & 99 & 125 & 240 & 307 & 557 & 450 & 450 & 325 & 287 & 197 & 143 & 76 \\
\hline & & ND+ & 2 & 3 & 6 & 8 & 14 & 11 & 11 & 8 & 7 & 5 & 4 & 2 \\
\hline & \multirow[b]{2}{*}{120} & Net & 113 & 151 & 291 & 372 & 674 & 544 & 544 & 393 & 348 & 238 & 173 & 91 \\
\hline & & ND+ & 3 & 4 & 7 & 9 & 17 & 14 & 14 & 10 & 9 & 6 & 4 & 2 \\
\hline & \multirow[b]{2}{*}{160} & Net & 124 & 167 & 320 & 409 & 741 & 599 & 599 & 432 & 382 & 262 & 191 & 101 \\
\hline & & $\mathrm{ND}+$ & 3 & 4 & 8 & 10 & 18 & 15 & 15 & 11 & 10 & 7 & 5 & 3 \\
\hline
\end{tabular}

Net $^{*}=$ Net drip irrigation requirements (L./tree/day), and

$\mathrm{ND}+=$ The number of drippers needed/tree.

\section{REFERENCES}

Abdelrahman, W.A. and Al-Nabulsi, Y.A. (1993). Irrigation water use of date palm. The third Symp. on the date palm in Saudi Arabia. Jun. ${ }^{\text {th }} 17-20$, 1413 H, Vol. (1): 273-281.

Abou Khalid, A.; Chaudhry, S.A. and Abdel-Salam, S. (1982). Preliminary results of date palm irrigation experiment in Central Iraq. Date Palm Journal, 1 (2): 199-232.

Al-Amoud, A.I.; Bacha, M.A. and Al-Darby, A.M. (2000). Seasonal water use of seller date palms in Saudi Arabia. International Agric. Eng. J. (2): 5162.

Al-Kafaf, S.; Al-Shiraqui, R.M.K. and Shabana, H.R. (1998). Irrigation scheduling of palm trees in the United Arab Emirates. The first international conference on date palm. Al- Ain, United Arab Emirates, March, 8-10:337-353.

Al-Omran, A.N. and Shalaby, A.A. (1992). Calculation of water requirements for some crops in the eastern and central regions of the Kingdom of Saudi Arabia. J. King. Saudi Univ. Agric. Sci. 4 (1): 95-114.

Fayoum J. Agric. Res. \& Dev., Vol.20, No.1, January, 2006 
SCHEDULING SUPPLEMENTARY DRIP IRRIGATION.

Aly, S.A. (2000). Contribution from ground water to water requirements of some crops. M.Sc. Thesis. Faculty Agric. Fayoum, Cairo Univ., Egypt.

Caspari, H.; Brhboudiam, M.H. and Chalmers, D.J. (1994). Water use, growth and fruit yield of "Hasu" Asias pears under deficit irrigation. J. Amer. Soc. Hort. Sci., 119 (3): 383-388.

El-Shakweer, M.H.A., Fathi, A. and M. A. Barakat (1982). Effect of ground water level on legume crops in Fayoum Governorate:1-Contribution to evapotranspiration of Vicia faba. Annals Agric. Sci. Ain Shams Univ. (Egypt) Bull. No.1863, June 1982.

El-Shakweer, M.H.A (1985). Effect of ground water level on legume crops in Fayoum Governorate: 4- Soil respiration and enzymes activities associated with faba bean. Commun. in Science \& Develop. Research, 10 (96): 95-104

F.A.O. (1979). Yield response to water. F.A.O.Irrigation and Drainage Paper No.33, (Rome).

Hassan, H. M. (1980). Effect of water table depth on irrigation requirements. Ph.D Thesis, Fac. Agric., Cairo Univ., Egypt.

Hussein, F. and Hussein, F. A. (1983). Effect of irrigation on growth, yield and fruit qualitiy of dry dates grown at Asswan. Proc. The first Symp. on Date Palm in Saudi Arabia.168-173.

Hussein, G.; Al-Ghadi, A. S.; Al- Qahtani, M.S.; Al-Bogliae, K. and AbdelSalam, M.O. (1993). Water requirements of date palm in Al-Hassa, Kingdom of Saudi Arabia. The third Symp. on the date palm in Saudi Arabia. Jan. ${ }^{\text {th }}$, 17-20, 1413 H. Vol. (1); 217-230.

Ibrahim, M. (1983). The capillary rise flux within the root zone of corn in the Nile Delta soil with shallow water table. J. Agric. Res. Tanta Univ. 9:217223.

Jensen, M.E.; Burman, R.D. and Allen, R.G. (eds.) (1990). Evapotranspiration and Irrigation Water Requirements. Amer. Soc. Civil Eng. No. 70, New York, U.S.A.

Kharshenko, S.E.; Roo S.S. and Volkov A.S. (1971). Irrigation timing and application amounts using thermal-water balance method (In Russian). Leningrad (1971) p 30.

Klute, A. (ed.) (1986). "Methods of Soil Analysis- Part,1- Physical and Mineralogical Methods" $2^{\text {nd }}$ (ed.). Amer. Soc. of Agron., Madison, Wisconsin, U.S.A.

Livett, d.G.; Simpson, J. R. and Tipton, J.L. (1995). Water use of landscape tree species in Tucson, Arizona., J. Amer. Soc. Hort. Sci., 1201 (3): 409-416.

Morrison, R.D. (1983). "Ground Water Montoring: Technology, Procedures, Equipments and Application" TIMCOMFG, Inc., Wisconsin, U.S.A.

Nail, A.M.A. (2003). Water requirements and effect of some irrigation regimes on growth nd yield of seewy date palms grown in Fayoum Governorate. Ph.D Thesis, Fac. of Agric., Fayoum, Cairo Univ., Egypt.

Page, A.I.; Miller, R. H. and Keeney, D. R. (eds.) (1982). "Methods of Soil Analysis" Part-2- Chemical and Microbiological Properties. 2 ${ }^{\text {nd }}$ (ed.). Amer. Soc. of Agron., Madison, Wisconsin, U.S.A.

Paratap, S.; Kumar, R.; Singh, P. and Ranver, K.(1994). Evapotranspiration from wheat under a semi- arid climate and shallow water table. Agric. Water Manag., 23: 91-108.

Fayoum J. Agric. Res. \& Dev., Vol.20, No.1, January, 2006 
SCHEDULING SUPPLEMENTARY DRIP IRRIGATION.

Ragab, R. A. and Amer, F. (1988). Predicting water table contribution to crop evapotranspiration in central Nile Delta by the CUF model. Zeitschrift Fur-Kulturtechnik Und Land Entwiklug. 30: 217-222.

Salvadore, J.L. and Smajstrla, A.G. (1996). Water application scheduling by Pan evaporation for drip irrigated tomato. J. Amer. Soc. Hort. Sci., 21 (1): 63-68.

Slimani, M. S. and Zayani, K. (1998). Water supply, growth and yield Deglet Nour palm trees in the Atilet-Nefzaoua Experimental Station (Tunisia). Medit. 1998, 9: 58-62.

Snyder,R.L.(1993). Irrigation Scheduling. Univ. of California, Davis,: 12-18.

Xainying, Xu.; Rendue, Z.; Xuzhang, X. and Ming, Z. (1998). Determination of evapotranspiration in the desert area using lysimeters. Communication Soil Sci. and Plant Annuals, 29: 1-13.

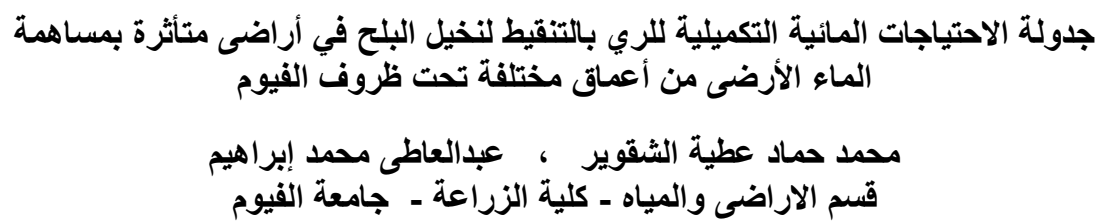

يهدف منتجي نخيل البلح إلى تطبيق أفضل المعاملات الزر اعية للتوصل إلي أفضل إنتاج ذو جودة عاليـة

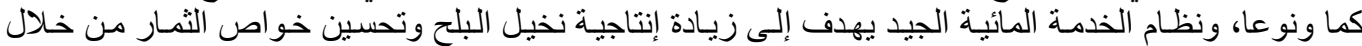

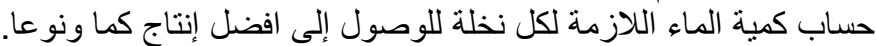

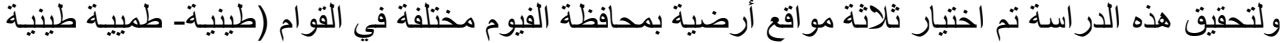

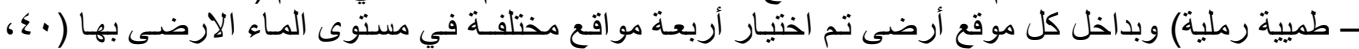

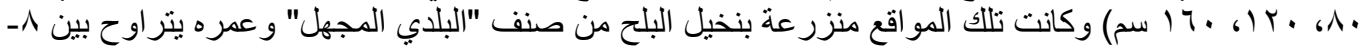

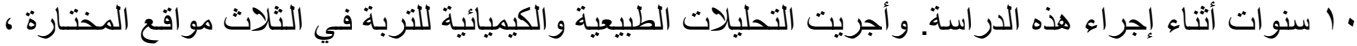

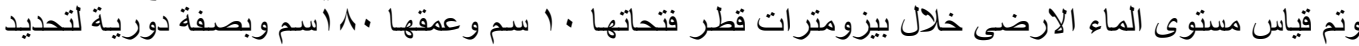

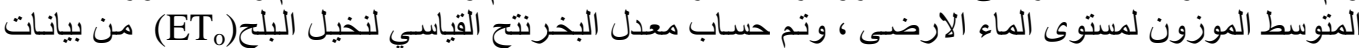

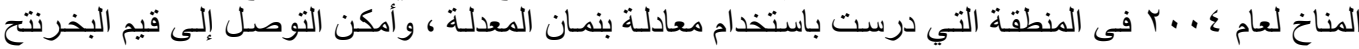

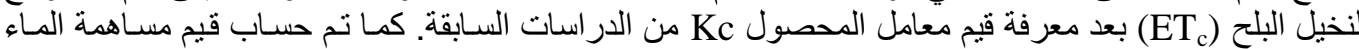

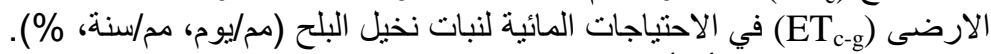

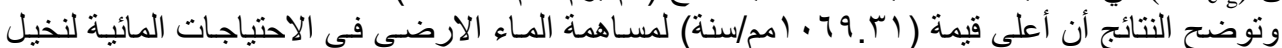

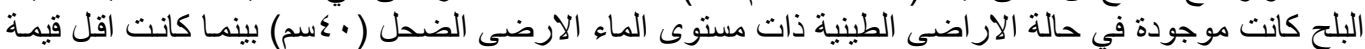

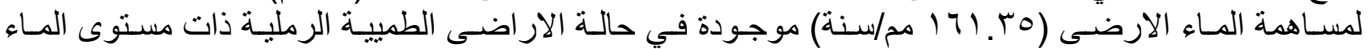

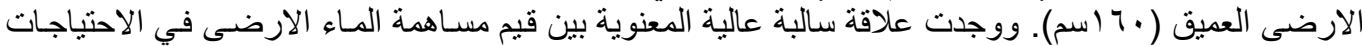

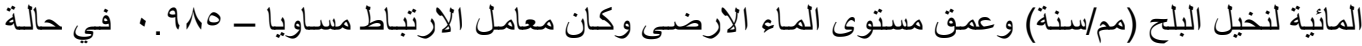

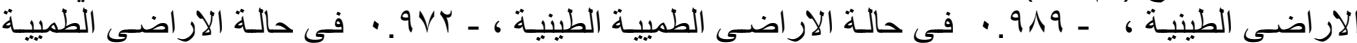

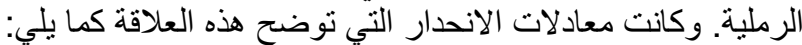
(للتربة الطينية)

للتربة الطمبية الطينية)

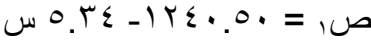

(للتربة الطميية الرملية الطمية الطبة)

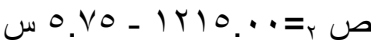

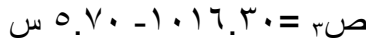

$$
\text { حيث: ص هي قيم مساهمة الماء الارضى فى الاحتياجات المائية لنخيل البلح (مم/سنة). }
$$

$$
\text { س هي مستوى الماء الارضى هي (سم). }
$$

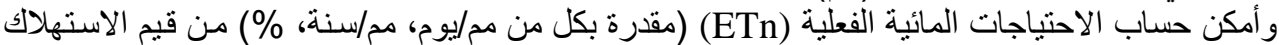

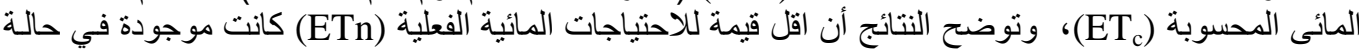

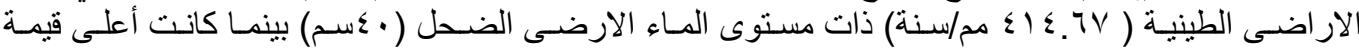

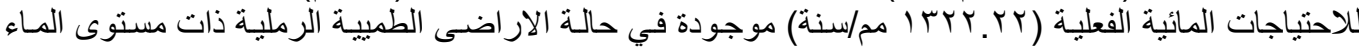

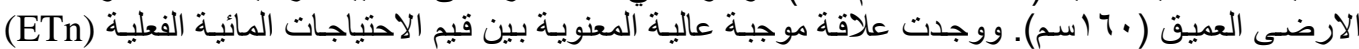

Fayoum J. Agric. Res. \& Dev., Vol.20, No.1, January, 2006 


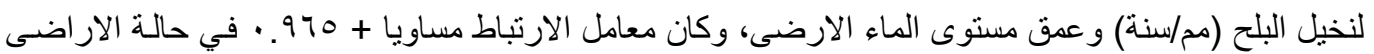

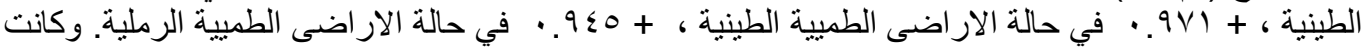
معادلات الانحدار التى توضح هذ هذه العلاقة كما يلي:

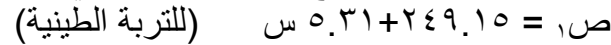

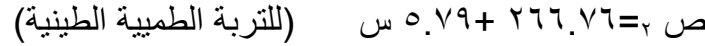

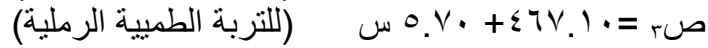

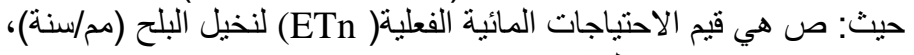

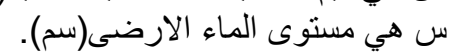

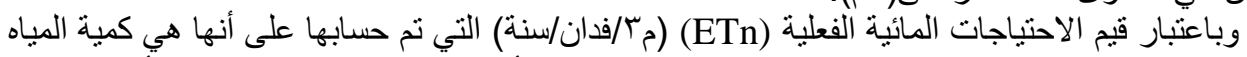

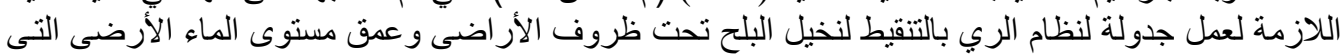

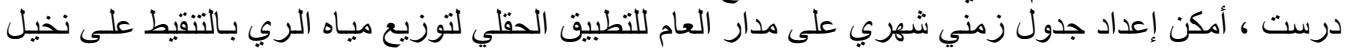

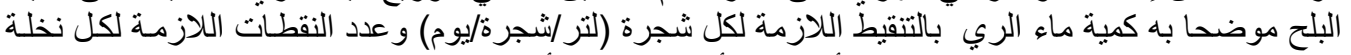

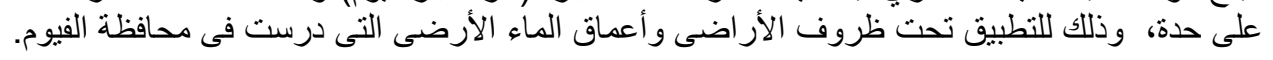

